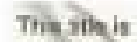

nowindexed

in Ecopsin

atoritus

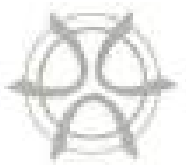

PL.ANNING MALAYSIA

Geospatial Analysis in Urban Planning

Volume II (20/3), Page 75 - 100

\title{
ASSESSMENT OF NEIGHBOURHOOD AFFORDABILITY BASED ON HOUSING AND TRANSPORTATION COSTS IN KUALA LUMPUR, MALAYSIA
}

\author{
Soheil Sabri ${ }^{1}$, Ahmad Nazri M. Ludin ${ }^{2}$ \& Foziah Johar ${ }^{3}$ \\ ${ }^{120.5}$ Centre for Innowative Planning and Development (CiPD) \\ UNIVERSITI TEKNOLOGI MALAYSIA
}

\begin{abstract}
One of the primary aims of transit-oriented development (TOD) is to reduce auto dependency, especially for low-income as well as senior residents. This study aims at providing some guiding principles for development of affordable housing with respect to TOD concept. As such, the study employed an index called Affordability Index (AI) and adapted for the study area to assess the neighbourhoods' affordability, It is composed of bousing cost, household transportation cost, and household income. The analyses were conducted on three neighbourhoods in Kuala Lumpur, Malaysia. The results reveal that the AI is lower for both owners and renters in the neighbourhood farther away from the LRT station, where there is less public transit facility, despite the existence of more affordable housing On the contrary, the index is high in the neighbourhood where the distance to L.RT station is shorter, connectivity index is higher, and there are more public transport facilities, despite the presence of high- and medium-cost housings. These findings can be used to plan for suitable public transport facilities in view of neighbourhood aftordability.
\end{abstract}

Keywords: TOD, Affordability Index, Transportation Cost, Housing Cost, Kuala Lumpur

\footnotetext{
'Senice Lecturer, Centze for lasovathe Planting and Dexelopment, Univeniti Teknolog Malaysa. fimail: soheilaratm.ny (Corresponding Author)
} 


\section{INTRODUCTION}

Smart growth has been defined as a set of goals, and policy mechanisms to achieve them, which serves as an alternative to sprawl (Aurand 2010). Smart growth is considered as one of the new urban development concepts in which a great opportunity for pleasant, hospitable, and economically beneficial conditions for living, working and recreation is desired (Weitz and Waldner 2002). According to The American Planning Associations' 2002 policy guide, the smart growth focuses on a compact, transit accessible, pedestrian-oriented, and mixed-use development patterns. Refocus of smart growth on inner parts of the cities in order to reduce the share of growth that occurs on newly urbanizing land, existing farmlands, and in environmentally sensitive areas is recently appreciated by governments.

Transit-oriented development (TOD) is instrumental in achieving the smart growth initiatives. TOD is often defined as higher-density mixed-use development within walking distance of transit stations. It aims at creating high density, pedestrian-oriented communities living in a mixed-used urban context (Litman 2007). TOD which promotes public transport will be most beneficial if combined with affordable housing (Mu and Jong 2012). Contemporary planning has not incorporate the cost of transportation in the provisions of affordable housing, although it has become one of the larger share of the household budget (Department of statistics Malaysia 2011). However, the current land use development pattern generates more urban journeys. According to Cenire for Transit Oriented Development \& Centre for Neighbourhood (2006), U.S. families living in neighbourhoods with greater residential density, a greater diversity of land uses and transit services spend less than $10 \%$ of their income on transport as compared with $19 \%$ by the average U.S. household.

As such, the efficacy of TOD in reducing individual's auto use is directly related to accommodating the residents who are not able to use private cars. Two main groups are mainly considered in this regards, namely, lowincome househoids and senior citizens. The combination of mixed-income housing and TOD is regarded as a possible solution to this issue (Belzer et al. 2007). However, there are barriers in joining mixed-income and transit-oriented neighbourhoods. The current literature on US cities suggests that the social equity goals of TOD have not been achieved in most cases.

A large and growing body of literature has been published on the impact of TOD on property value and demand. Some of the main issues are related to the complicated and expensive nature of TOD (Debrezion et al. 2007, 
Hess and Almeida 2007). Others, argued that the demand for housing near transit stations should be socially desirable and increase the number of residential units in a TOD project (Cervero and Duncan 2001, 2002a,b; Winston and Maheshri 2007). Hence, the synergy between economic, land use, transportation, environment, housing, equity goals and TOD is not automatically achievable. Due to demographic, institutional and geographical differences, it is however diflicult to generalize these studies (Duncan 2011). This study reviews the TOD and affordable housing in the context of Kuala Lumpur (KL), Malaysia, us an example of rapidly growing city.

This paper is divided into four parts. The first part deals with theoretical debates on TOD, affordable housing, and affordability index. The second part describes the design of affordability index model in Kuala Lumpur context. The third part presents the results of developed model in three KL neighbourhoods and evaluates the model by discussing the findings. The concluding remarks are presented in the fourth part of the paper.

\section{TRANSIT-ORIENTED DEVELOPMENT}

Transformation of cities through innovative public transport systems aims at providing more services to residents (Rimmer and Dick 2009). The literature suggests several reasons for developing urban public transit systems. Those reasons are declining traffic congestion, stimulating development, serving the central parts of the city, and improving the environment (Kim et al. 2007). Furthermore, these systems provide service to a wide range of residents by different income, age, gender as well as other urban activities such as commercial, institutional, and recreational.

Public transit potentially delivers congestion relief, reduces energy consumption, air quality improvement, and economic development (Litman 2012). In the US, several groups such as community-based developers, planners, and business leaders have already embraced TOD. It is also admired by advocates of transit and smart growth as a viable strategy that creates opportunity and accessibility for low-income households, and urban revitalization (PolicyLink 2008). It is believed that a community or a city, which is designed adhering to TOD principles, is able to move more passengers with lower spatial requirements (Mu and Jong 2012).

Preliminary work on TOD was undertaken by Calthorpe (1993) drawing on the future trajectories of American cities. He provided new planning guidelines as alternatives to housing, traffic, environmental, and social issues 
caused by urban sprawl. Therefore, many American cities such as San Diego, San Francisco, and Boston have adopted TOD principles (Kahn 2007; Duncan 2011; Hess and Almeida 2007). There is a vast literature on good practices of TOD in European and Asian cities (Mu and Jong 2012). However, the synergy between all goals of TOD such as economic, land use, transportation, environmental, housing and equity are not achieved in most cases (PolicyLink 2008).

Many claimed to be TOD projects are not fundamentally different from traditional residential suburban developments. They are not well-integrated with the station or the surrounding community, and they are neither mixed-use nor mixed-income. For instance, Cervero and Duncan (2001), who investigated the land value effects of proximity to light and commuter rail stations on Sinta Clara County. California, highilighted a substantial capitalization benefits for commercial lands. Similar study conducted on Buffalo, New York by Hess and Almeida (2007), indicated that a home located within one-quarter of a mile radius of a light rail station earns more compared with that of the city's median home value. Other studies (Cervero and Duncan 2002a,b; Duncan 2011) also conclude the likelihood that TOD housing will be unaffordable to low-income households. In other words, TOD can produce gentrification, which replaces the affordable housing and low-income residents by high-end residential, commercial, or offices (Kahn 2007). For instance, Cho-yam Lau (2011) reported a spatial mismatch caused by redevelopment of central area into business district in Singapore. The low-income residents have to spend a considerable pereentage of their income and time going to work.

One question that needs to be answered, however, is to what extent the proximity to transit infrastructure reduces the overall household expenditure. A variety of influential factors for implementing an equitable TOD is reported in numerous academic and government documents. Among these factors, governance (including tax incentives and alternative transport service coordination) (Levine 2005; Cho-yam Lau 2011), land use (including density and diversity) (Cho-yam Las 2011; Kim et al. 2007; Chakraborty and Mishra 2013), urban design (including pedestrian friendly design, designs with human scale characteristics, safety and security) (Jacobson and Forsyth 2008), urban policy (protection from displacements, and securing local communities' benefits of TOD) (Cervero 2007; Winston and Maheshri 2007), expanding multi-centric developments and management of real estate market (Cervero and Duncan $2002 \mathrm{~b}$, Debrezion et al. 2007) are considered as priorities in achieving an equitable TOD principle: 


\section{AFFORDABLE HOUSING.}

Generally, housing affordability involves the capacity of households to consume housing services; specifically, it involves the relationship between household incomes and housing expenditure. If expenditure on housing relative to income is reasonable or moderate, it is considered ths affordable (Kutty 2005). Affordability is commonly measured based on the ratio of housing costs to income. The rule of thumb in US, Australia, and most of Europe is that households exceeding $30 \%$ of the expenditure on housing, are identified as baving an aftordability problem (Nelson et al. 2002; Kutty 2005).

This approach, however, does not consider whether the income available after the housing expenditure is adequate to meet other household needs, such as transportation, food, cloth, education, and health care. In reoent years, there has been an increasing criticism on this approach because of its normative and arbitrary nature (Hulchanski 1995; Kutty 2005; Mulliner et al., 2012; Stone 2006; Seelig and Phibbs 2006). In contrast to the conventional way of measuring affordability. Kutty (2005) and Stone (2006) recognise that housing affordability should address the issue of large families with more needs versus the one- or two-person households. Their approach, which is known as 'shelter poverty' measure or residual income, considers the adequacy of household income to cover both housing costs and non-housing costs.

However, the residual income approach shares some shortcomings of the ratio measure, such as inability to cover the housing condition and impacts of location (Mulliner et al. 2012). Bogdon and Can (1997) question whether the condition, location and neighbourhood characteristics of the housing are as important as housing price and standards. Recently, literature has offered contradictory findings about affordability and satisfaction in different places and times. For instance, Mulliner et at. (2012) argued that environmental and social sustainability must also be taken into consideration for measuring the affordability in the UK. They identified 13 social sustainability indicators, such as availability of affordable home ownership products, safety (erime level), quality of housing, and access to public services and facilities. In addition, they identified four environmental sustainability indicators namely, energy efficiency of housing, availability of waste management facilities, and presence of environmental problems. Other studies suggested more planning, management, and regulatory factors such as, density and mixed-use development, growth manigement initiatives, regulatory tax, local land use controls, and building regulations (Nelson et al., 2002; Aurand, 2010; Cervero and Duncan 2002b; Cheung et al. 2009; Glaeser and Gyourko 2001; Quigley et al. 2004). 
In Malaysian context, studies on housing quality and affordability have indicated the importance of neighbourhood facilities, environment, housing costs and types, and length of residency (Salleh 2008; Tan 2012; Salfarina et al. 2011; Mohit et al. 2010), Salfarina et al. (2011) proposed to include the quality of life and satisfaction on housing and neighbourhood conditions in measuring affordability of housing in Malaysia, Similar to the argument of Bogdon and Can (1997), Salfarina et al. (2011) agreed that besides house price, the Malaysian urban residents are also concerned about location, neighbourhood, and distance from work place. In addition, the period of housing ownership which influences the socio-cultural interactions as well as access to religious facilities are considered by Malaysian households. However, these factors have yet to be included in measuring the affordability of housing in neighbourhood level in the Malaysian context.

The Malaysian government has been committed to provide adecjuate, affordable and quality housing for all Malaysia, particularly the low income group as addressed by the Seventh (1996-2000), Eight (2001-2005), Ninth (2006-2010), and Tenth (2011-2012) Malaysia plans (Government of Malaysia, $1996,2001,2006,2010$ ). As a strategy for transportation planning, the Ninth Malaysia Plan suggested that the commuter, LRT and monorail systems be improved by taking into account the growth of new residential areas, new commercial centres and complexes, new public infrastructure such as schools and also population growth and density around transportation networks (Government of Malaysia 2006). Nevertheless, these systems need to be integrated comprehensively with a wider network in order to become more effective. The Tenth Malaysia Plan 2011-2015 initiated the Urban Public Transport as one of six National Key Result Areas (NKRA) which to considerably increase public transport ridership in three urban areas: Greater KL. Pulau Pinang and Johor Bahru. This plan promotes mixed-use developments, which ealis for building high-density mixed-use developments, which must be integrated with a well-functioning public transport system. However, no attempt was made to quantify the association between TOD and affordable housing in implementing the government initiatives.

The findings from literature indicate that most factors related to affordable bousing and TOD are similar and interchangeable. Both of them seek to provide a reliable quality of life for houscholds. However, affordable housing and TOD as smart growth components are likely to be in controversy (Cervero 2007). Hence, a supportive policy should foster the affordable housing implementation in well-serviced locations of the city. Real affordable housing 
index should serve as a decision support tool to help the government and other advocates to formulate accurate policies.

\section{METHOD AND MODEL}

Since this study is considering both affordable housing and TOD as the components of smart growth, it would be relevant if the meaning of affordability is redefined using new components such as neighbourhood characteristics, accessibility, and socio-economic factors. The Centre for Neighbourhood Technology (CNT) has introduced a new affordability index, called " $\mathrm{H}+\mathrm{T}$ Affordability Index", by adopting housing and transportation costs (Haas et al, 2008). The index is tested on several US metropolitan areas. To date, there is no report on the application of this index on international level. Nevertheless, in order to adopt the $\mathrm{H}+\mathrm{T}$ affordable index on other cities than US, it is necessary to consider the local characteristics and requirements. This section presents the new conceptualisation of $\mathrm{H}+\mathrm{T}$ affordable index based on Malaysian context.

The neighbourhood characteristics determine housing type, affluency of households and the amount of money spent on transportation, thus the characteristics outline the transportation demand (Dissanayake et al. 2012). The neighbourhood characteristics can be divided into two: physical, and accessibility. The former characteristics are density, walkability, and availability and quality of transit service. The later characteristics include access to facilities like shopping, health centre, school, and entertainment or access to job. Neighbourhoods with all these characteristics are considered as "location efficient" (Soo et al. 2008), where the housebold cost is lower than the others. These costs should be considered in the housing affordability standards which can be used in allocating low-income housing incentives and schemes. Figure 1, indicates the conceptualization of affordability index based on housing and transportation costs in Malaysian context. Providing both housing and transportation facilities allow low-income households to get access to better quality of life. This combination also provides a substantial incentive to the private sector to invest in transit-oriented locations, and supports the public sector in making investments that reduce household transportation costs. The affordability of a home, therefore, can be calculated based on the market value and the transportation costs acquired in each location. It is possible also to perform the measurement in both regional and local levels. In both Jevels, the decision makers can investigate the different needs of communities and the distribution of services, thus enhancing affordability. 


\section{Affordability Index Modfel}

There are three general factors in calculating affordability index $(A /)$, namely housing cost $\left(\mathrm{H}_{\mathrm{e}}\right)$, transportation cost $\left(\mathrm{T}_{\mathrm{t}}\right)$ and neighbourhood income $\left(\mathrm{N}_{1}\right)$. The housing cost includes current housing sales price and rents, while transportation cost is measured based on the sum of auto ownership, auto use, and public transit costs as three separate components. The neighbourhood income is the average income of houscholds in the neighbourhood.

$$
A J=\left(H_{c}+T_{c}\right) / N_{l}
$$

The three components of transportation cost are the dependent variables which are affected by nine independent variables, seven which are built environment variables, and two are household variables. Table 1 includes all the dependent variables and Table 2 summarizes the independent variables. These variables represent the neighbourhood and socio-economic characteristics that affect the household transportation costs. The resolution of the model is based on the census data tract, although the best resolution would be at the scale of enumeration block that represents the neighbourhood characteristics.

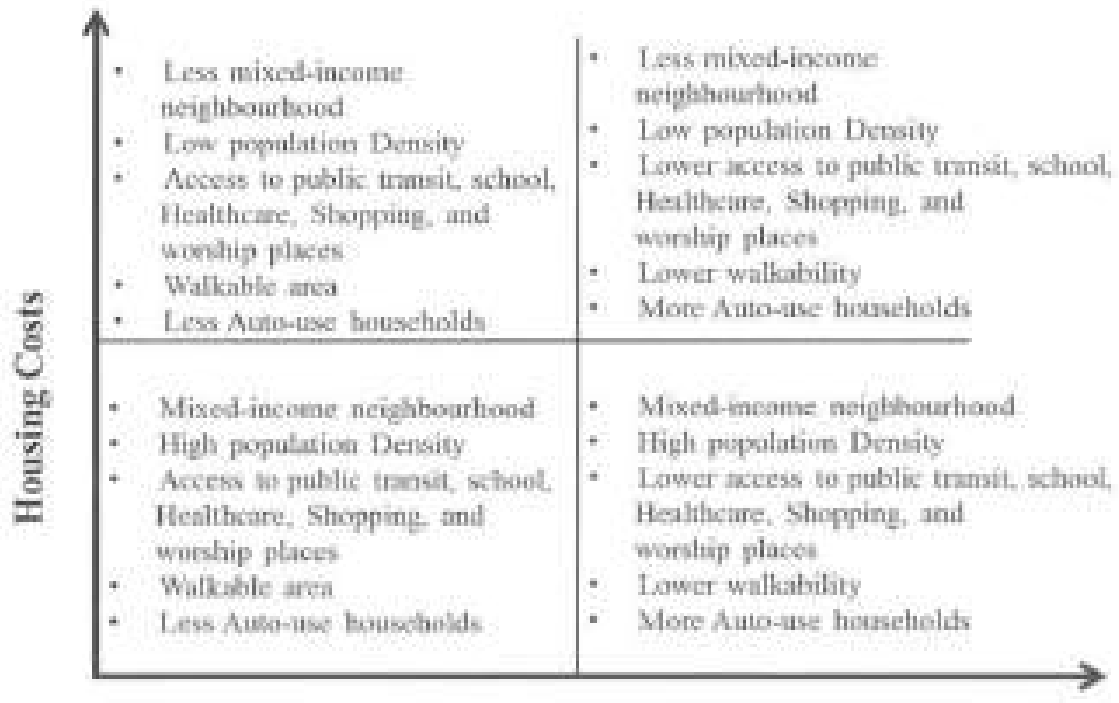

\section{Transportation Costs}

Figure 1: Conceptual framework for Affordability Index 
Table 1: Dependent Variables in the Transportation Cost Model

\begin{tabular}{|c|l|l|}
\hline \multicolumn{1}{|c|}{ Dependent Variables } & \multicolumn{1}{|c|}{ Source } & \multicolumn{1}{|c|}{ Purpose } \\
\hline $\begin{array}{l}\text { Auto ownership (vehicles } \\
\text { per household) }\end{array}$ & $\begin{array}{l}\text { Calculated based on independent } \\
\text { houssohold and local environinent } \\
\text { variables }\end{array}$ & $\begin{array}{l}\text { To determine the } \\
\text { mumber of auto- } \\
\text { ownership by each } \\
\text { household and } \\
\text { ownership costs }\end{array}$ \\
\hline $\begin{array}{l}\text { Auto use (annual miles } \\
\text { driven per household) }\end{array}$ & $\begin{array}{l}\text { Calculated based on household } \\
\text { travel strvey and vehicle miles } \\
\text { travelled fitted to the independent } \\
\text { variables }\end{array}$ & $\begin{array}{l}\text { To deternine the } \\
\text { mileage a household } \\
\text { drives each vehicle and } \\
\text { usage costs }\end{array}$ \\
\hline Transit rides per day & $\begin{array}{l}\text { Calculated based on independent } \\
\text { housebold and local environment } \\
\text { variables }\end{array}$ & $\begin{array}{l}\text { To deternine the } \\
\text { number of transit riders } \\
\text { per day per household }\end{array}$ \\
\hline
\end{tabular}

Table 2: Independeat Variables in Transport Cost Model.

\begin{tabular}{|l|l|}
\hline \multicolumn{1}{|c|}{ Independent Variables } & \multicolumn{1}{c|}{ Purpose } \\
\hline $\begin{array}{l}\text { Houschold per resideatial area unit } \\
\text { (e.g. Acre, Hectare) }\end{array}$ & $\begin{array}{l}\text { Measures the density, which influences auto } \\
\text { ownership and use }\end{array}$ \\
\hline $\begin{array}{l}\text { Household per total area unit } \\
\text { (c.g. Aure, Hectare) }\end{array}$ & $\begin{array}{l}\text { Measures the density, which influences auto } \\
\text { ownership and use }\end{array}$ \\
\hline $\begin{array}{l}\text { Average block size in area unit } \\
\text { (e.g. Acre, Hectare) }\end{array}$ & $\begin{array}{l}\text { Contributes to the walkability of area, which } \\
\text { influences on three dependeat variubles }\end{array}$ \\
\hline Transit Counectivity Index & $\begin{array}{l}\text { Availability and extent of trinsit, which } \\
\text { influence transit use }\end{array}$ \\
\hline Distance to job centre & $\begin{array}{l}\text { Access to job influences auto-ownership and } \\
\text { auto-use }\end{array}$ \\
\hline Job density and access & $\begin{array}{l}\text { Number of jobs per square area unit } \\
\text { (e.g. Mile, Kim) Influences three dependent } \\
\text { varinbles }\end{array}$ \\
\hline Access to facilities & $\begin{array}{l}\text { Existence of nearby services influences three } \\
\text { dependent variables }\end{array}$ \\
\hline Household income & Influences auto-ownership and use \\
\hline Household size & Influences auto-ownership and use \\
\hline
\end{tabular}

A spatial interaction model determines proximity to the employment centres (Birkin et al. 1996). It considers the number of and distance to all available jobs related to the neighbourhood. The flow of people is calculated by two main hypotheses: 1 . Flows between residential aneas and job centres will be proportional to the attractiveness of the job centre rather than all other 
competing destinations. 2. Flows between residential areas and job centres will be proportional to the relative accessibility of that centre rather than other competing centres (Equation Eq. 2).

$$
F_{i j}=A_{i} \times O_{i} \times W, \times f\left(d_{i j}\right)
$$

Where, $F_{i j}$ is the job accessibility, $O_{i}$ is the total number of potential job seekers in the neighbourhood (representing the demand factor), $W_{j}$ is a measure of the attractiveness of centre $j, d_{i j}$ is the distance from the centre of the neighbourhood $i$ to the job centre $j$, and $A_{j}$ is a balancing factor wich takes account of the competition and ensures that all demand is allocated to job centres in the region. It is written as:

$$
A_{i}=1 / \sum_{j} w_{j} \times /\left(d_{i j}\right)
$$

In order to estimate the three dependent variables of transportation cost, namely, auto ownership, auto use, and transit use, different methods and data sources should be used. The auto ownership in each neighbourhood is determined based on the vehicles per bousebold, and the eosts are based on Malaysian standards and ayailable data on depreciation, finance charges, insurance, and license, registration and taxes. Similarly, auto use should consider the local costs such as fuel price, maintenance, and repairs.

The transit use costs also are very dependent on data availability. There are seyeral sources to estimate the transit use costs such as the report on total revenue of transit agencies, and reports on total passenger trips (Ministry of Transportation, 2010).

The general model of transportation cost is presented in Equation Eq.4. Auto ownership $\left(A u_{i}\right)$, auto use $\left(A u_{u}\right)$, and public transport $\left(P u b_{f}\right)$ are functions of the local environment $\left(V_{l e}\right)$ characteristics, and household income and size $\left(V_{H h}\right)$

And

$$
T_{t c}=\left[C_{A u_{o}}{ }^{*} F_{A u_{o}}(V)\right]+\left[C_{A u u_{u}}{ }^{*} F_{A u}{ }^{(V)}\right]+\left[C_{P u b_{i}}{ }^{*} F_{P u b_{i}}{ }^{(V)}\right]
$$

$$
V=V_{l e} V_{H h} \quad(\text { Eq. } 5)
$$


In Equation Eq.4, $T_{t c}$ is the total transportation cost, and $C_{A a_{o}}, C_{A u_{u}}$ and $C_{P u b_{t}}$ are cost factors of auto ownership, auto use, and public transit use respectively. Similarly, $F_{A u_{o}}, F_{A_{u} u}$, and $F_{P_{u b}}$ are functions of the independent variables for auto ownership, auto use, and public transit uses respectively, In order to construct the regression equations, each variable should be lested separately for two reasons. First, it determines the distribution of the sample, and second it shows the strength of relationship to the variable.

\section{CASE STUDY AND SAMPLE SELECTION}

Kuala Lumpur is selected for the case study which is the only urban arca that receives the transit service by both bus and light rail transit (LRT). The affordability of housing also is under quest in this city due to the concentration of services (Tan 2012). The 2010 Malaysian household consumption reported that families spent about a quarter of their income on food, followed by housing at nearly $20 \%$. The expenditure on transportation constitutes the third item at 13.4\% (Bank Negara 2010). According to the Department of statistics Malaysia (2011), generally, the average monthly household expenditure increased by $88.6 \%$ from RM1,161 in $1993 / 94$ to RM 2,190 in $2009 / 10$. A substantial increase was reported for housing, water, electricity, gas and other fuels $(102.0 \%)$, as well as transport $(94.6 \%)$ (Figure 2$)$. It is assunted, however, that the figure is different in Kuala Lumpur as the housing price and transportation cost is higher than other parts of the country. 


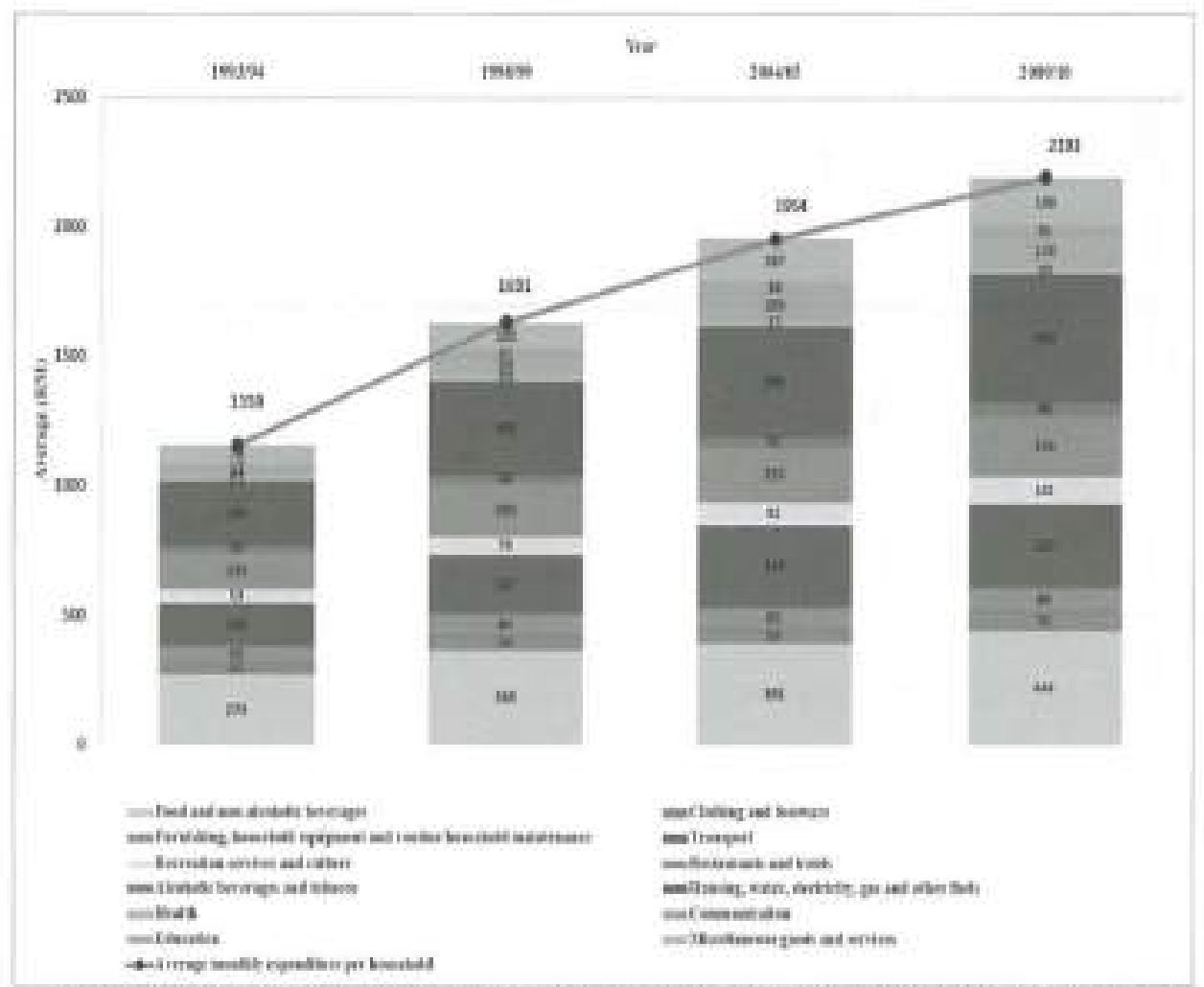

Figure 2: A verage monthly household expenditure, Malaysia, 1993/1994-2009/2010.

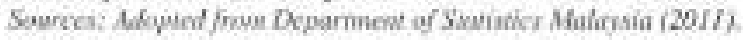

A low-cost house in Kuala Lumpur is generally priced at RM 42,000 which is considerably higher than other low-cost houses in other parts of Peninsular Malaysia, which is from RM 25,000 to RM 32,000. Thus, a household with a monthly income of less than RM 2,500 in Kuala Lumpur will have difficulties to spend only $20 \%$ for housing The transportation cost, however, maybe less than other parts of the country in ease the public transport is available for such households.

The traditional measure of affordability, however, ignores transportation costs which incur relatively high proportion of income. Combining housing and transportation costs offers an expanded view of affordability. In order to test this claim, three different neighbourhoods (Tamans) in Kuala Lumpur are selected. These are Taman Melati, Taman Setiawangsa, and Taman Teratai Mewah (Figure 3). 


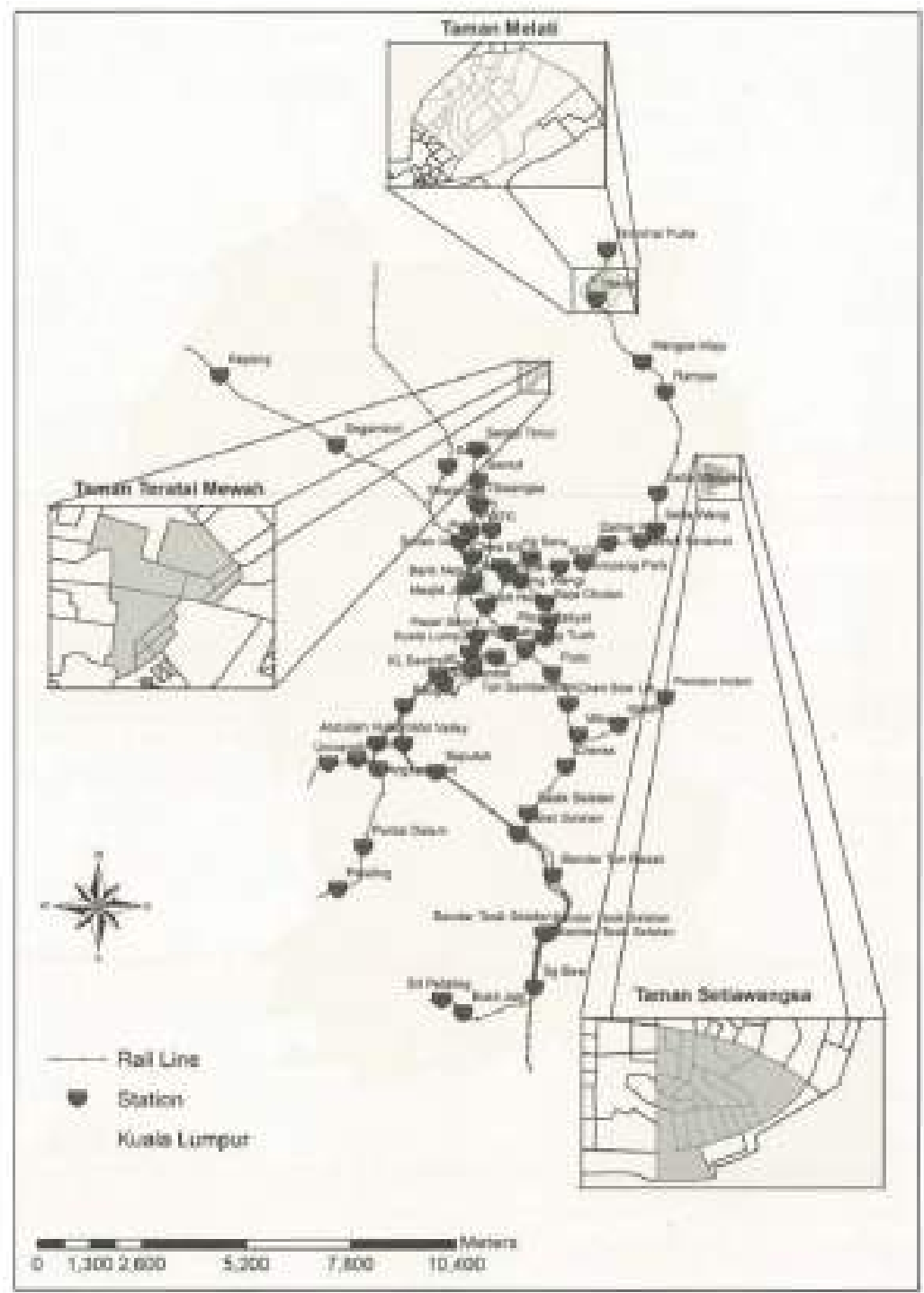

Figure 3: Location of Taman Teratai Mewah, Taman Melati, and Taman Setiawangsa in Kuala Lumpur.

Taman Melati and Setiawangsa are located in close proximity to two of Kelana Jaya LRT stations. The third Taman is relatively far from the nearest LRT station at $3.7 \mathrm{Km}$. Table 3 indicates the distance of each neighbourhood from the nearest LRT station. The density of bus stops in Taman Teratai Mewah is lower than two other neighbourhoods. 
Table 3: Distance to Nearest L.RT Station and the Number of Bus Stopg.

\begin{tabular}{|l|l|c|c|}
\hline Neigbourhood & \multicolumn{1}{|c|}{ Station } & Distance $(\mathbf{k m})$ & Bus Stops \\
\hline Teratai Mewah & Wangsa Maju & 3.7 & \\
& Melati & 3.7 & 2 \\
& Sentul Timur & 4.4 & \\
\hline Melati & Melati & 1.4 & 4 \\
& Terminal Putra & 1.2 & 4 \\
\hline Setiawangsal & Setiawangsa & 1.8 & 8 \\
\hline
\end{tabular}

The affordability of residential buildings in the three neighbourhoods is measured and mapped based on the income and rental price. The measurement of affordability is based on the classic definition that considers the percentage of income spend on housing and maintenance (Figure 4). The percentage of housing expenditure in Taman Melati is between $18 \%$ and $24 \%$, while the percentage in other two neighbourhoods is between $20 \%$ and $24 \%$. It means that the housing price and rental in Taman Melati are slightly more affordable than the other two, which is most likely due to existing public housing schemes such as "Public Housing Sri Tioman I" and "Public Housing Sri Tioman II". Despite the existence of medium-high cost housing in Taman Melati (Melati Utama Condominium), the housing expenditure remains at $18 \%$. 


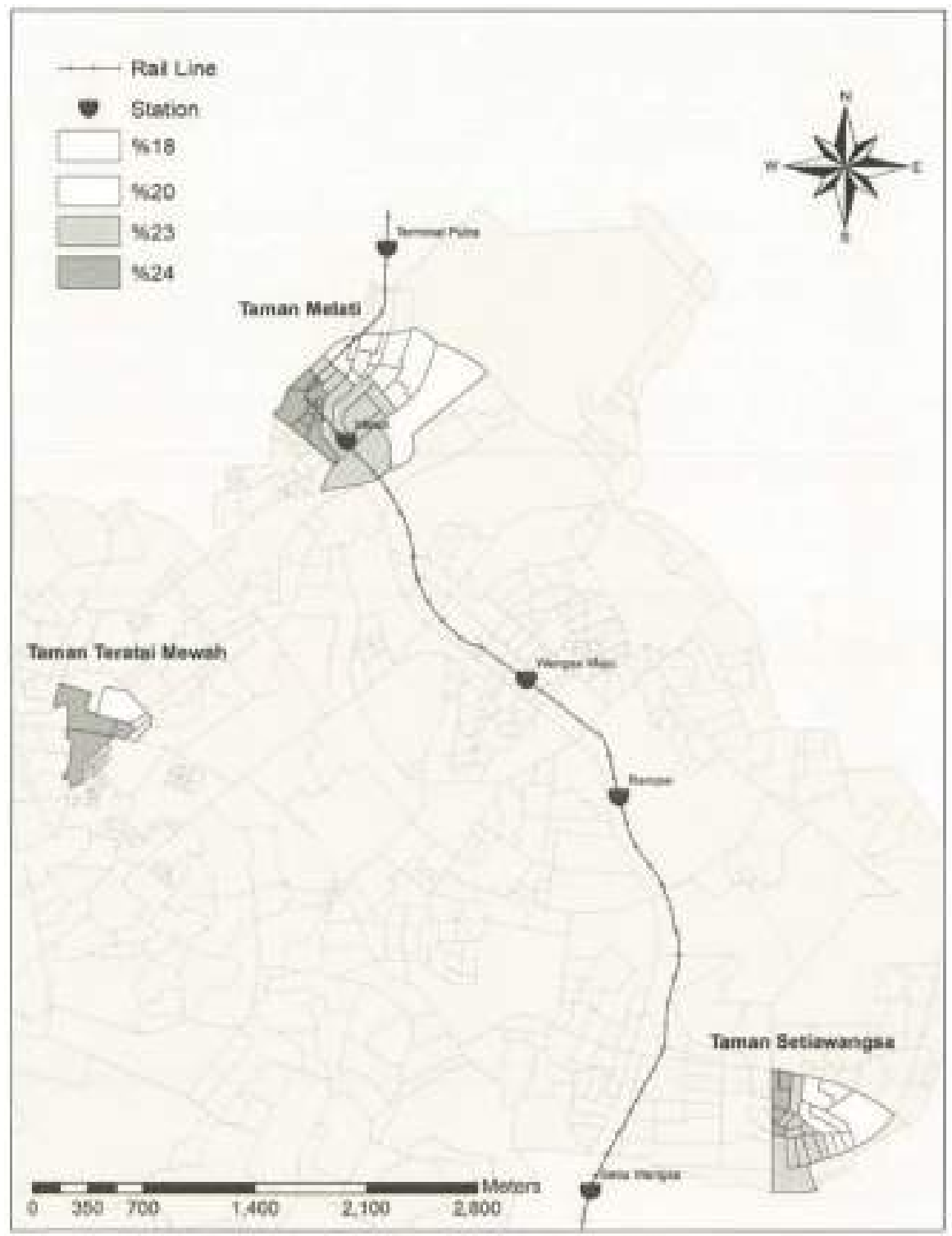

Figure 4: Percentage of Households' Expenditure on Housing

In Taman Teratai Mewah, the majority of residential buildings are medium-cost houses and the lowest rental value is RM 600. However, there are residents eaming RM 2,800 a month, which are categorized as low-income, living in these houses. They would have to spend up to $24 \%$ of their income for housing. 
In Taman Setiawangsa there is a combination of low-cost (e.g., Menara Sri Pulai), medium-cost (e.g., Sri Cendana), and medium-high cost housing (e.g, Putra Apartment). The average rental value ranged from RM 300 in Menara Sri Pulai in Menara to RM 1,000 in Putra Apartment.

In order to measure the transportation cost, the independent variables are extracted from several databases. As mentioned before, the transportation services are different for each neighbourhood. Taman Melati has the best combination of transit rail and bus routes and stations, which explained the development of medium-high cost residential buildings during the last six years, In contrast, Taman Teratai Mewah is receiving the lowest public transportation service. The number of bus stops in this neighbourbood is as low as two; one near to residential area and the second one closed to the local shopping centre. Table 3 indicates that the nearest train station to Taman Teratai Mewah, which is twice farther than the other two neighbourhoods.

The number of bus routes and stops are higher in Taman Setiawangsa than the other two neighbourhoods. However, there is a poor connection between train station and bus services in this neighbourhood. Thus, the transportation cost for households is affected as they have to change the transport two times to reach the train station. The straight distance of Setiawangsa LRT station to the study area is about $1.6 \mathrm{~km}$. It is expected that access to the LRT station has to be supported by bus services. Conversely, the nearest bus stops to this station are about 400 meters, which adds to frustration in changing several modes of transport and consequently, a decline in ridership.

\section{MODEL IMPLEMENTATION AND RESULTS}

Table 4 shows the independent variables for each of the three neighbourhoods. The household costs are measured separately based on the tenure status, allowing the affordability index to be measured for both owner and tenant resident types.

As can be seen in Table 4, despite the lower annual median houschold income in Taman Teratai Mewah, the average vehicle per household as well as the pereentage of workers using private cars for the daily commute are higherThis is confirmed by the transit connectivity index, which is low in Teratai Mewah compared to the other two neighbourhoods. 
Table 4: Background information on three neighbourhoods of Melati, Setiawangsa, and Teratai Mewah

\begin{tabular}{|c|c|c|c|c|}
\hline $\begin{array}{l}\text { Independent } \\
\text { variable }\end{array}$ & Indicator & $\begin{array}{l}\text { Taman } \\
\text { Meluti }\end{array}$ & $\begin{array}{c}\text { Taman } \\
\text { Setiawangsa }\end{array}$ & $\begin{array}{c}\text { Taman Teratal } \\
\text { Mewah }\end{array}$ \\
\hline Demographies & $\begin{array}{l}\text { Number of } \\
\text { household } \\
\text { Avg household size }\end{array}$ & $\begin{array}{c}3,279 \\
4,2\end{array}$ & $\begin{array}{c}2,166 \\
4,1\end{array}$ & $\begin{array}{c}1.196 \\
3.5\end{array}$ \\
\hline Income Factors & $\begin{array}{l}\text { Annual median } \\
\text { household income } \\
\text { (RM) } \\
\text { Aninual median } \\
\text { household income } \\
\text { range (RM) }\end{array}$ & $\begin{array}{l}33,000 \\
18,000- \\
39,000\end{array}$ & $\begin{array}{l}45,500 \\
18,000- \\
90,000\end{array}$ & $\begin{array}{c}28,500 \\
18,000-39,000\end{array}$ \\
\hline $\begin{array}{l}\text { Density } \\
\text { Measures }\end{array}$ & $\begin{array}{l}\text { Walkability } \\
\text { Avg, households / } \\
\text { residential acre } \\
\text { Jobs / sq. mi. }\end{array}$ & $\begin{array}{c}1.18 \\
30.3 \\
21\end{array}$ & $\begin{array}{c}2.00 \\
49.98 \\
65\end{array}$ & $\begin{array}{c}5.2 \\
23.05 \\
5\end{array}$ \\
\hline $\begin{array}{l}\text { Access to } \\
\text { transit and jobs }\end{array}$ & $\begin{array}{l}\text { Percent commuting } \\
\text { by transit } \\
\text { Transit } \\
\text { Connectivity Index }\end{array}$ & $\begin{array}{l}10 \% \\
\text { High }\end{array}$ & $\begin{array}{c}10 \% \\
\text { Medium }\end{array}$ & $\begin{array}{l}7 \% \\
\text { Low }\end{array}$ \\
\hline $\begin{array}{l}\text { Housing and } \\
\text { transportation } \\
\text { cost indicators }\end{array}$ & $\begin{array}{l}\text { Avg montbly } \\
\text { mortgage payment } \\
\text { (RM) } \\
\text { Avg monthly reatal } \\
\text { payment (RM) }\end{array}$ & $\begin{array}{l}707 \\
590\end{array}$ & 778 & $\begin{array}{l}647 \\
500\end{array}$ \\
\hline
\end{tabular}

To calculate the total transportation costs, values for the unit of each component are determined. Ultimately, the aggregation of values concluded the specific transportation cost of each neighbourhood.

\section{Auto Ownership Costs}

There are several variables in auto ownership that can be assumed as fixed values in calculating the total cost. These are depreciation, finance charges, insurance, license, registration and taxes. Generally, the most used cars for low and medium-income houscholds in Malaysia are the local productions. In order to cover almost all engine classes, four years old Proton Persona with engine capacity of $1600 \mathrm{ce}$ is considered. The total ownership cost is estimated at RM14,000 based on usage miles per annum. Table 5 shows the percentage of each variable in estimating the car ownership cost. 
Table 5: Auto Ownership Cost Calculation.

\begin{tabular}{|c|c|c|c|c|c|c|}
\hline & $\begin{array}{l}\text { Tetal eost } \\
\text { per mile }\end{array}$ & $\begin{array}{l}\text { Depreciation } \\
\text { per mile }\end{array}$ & $\begin{array}{l}\text { Fisance } \\
\text { charges }\end{array}$ & $\begin{array}{l}\text { Iasurance } \\
\text { per mile }\end{array}$ & $\begin{array}{c}\text { Registration. } \\
\text { licenses, tus } \\
\text { per millt }\end{array}$ & $\begin{array}{l}\text { Ownership } \\
\text { east per mile }\end{array}$ \\
\hline Percent & 100,000 & 35.00 & 27.00 & 15.00 & 3.00 & 20.00 \\
\hline Vulue(RM) & 0.96 & 0.34 & 026 & 0.14 & 0.0129 & 0.77 \\
\hline Total (RM) & 13,520 & 4,732 & 3.650 & 2,028 & 405 & 17,816 \\
\hline
\end{tabular}

\section{Auto Use Costs}

Three variables are identified for auto use costs in this study, namely, fuel, maintenance, and repairs. These variables are largely different depending on type, age and level of usage. For simplicity. Proton Persona is again used to calculate the auto use cost. The maintenance and repairs per mile are taken as $5 \%$ and $2 \%$ of the total price, which are equivalent to RM0.07 and RM0.03 per mile respectively.

The fuel cost is calculated based on the 2010 price of regular petrol, which is RM 1.9 per litre. Thus, the fuel cost per mile is RM0.26, assuming the fuel consumption is 8.5 litre for 62.137 miles (equivalent to 100 kilometres). The total auto tse cost, which is equal to RM 0.35 per mile $(0.06+0.03+0.26)$, is then applied to the modelled results of average vehicle miles travelled (VMT) by each household. The VMT for each neighbourhocd is calculated based on trip generated by each household, data of which is obtained from the Kuala Lumpur City Hall.

\section{Transit Use Costs}

According to the Transport Statistics report (Ministry of Transportation 2010), the number of passenger trips in Malaysia has risen from 52.5 million in 2001 to 58 million passengers in 2010. Although, the highest number of passengers was recorded at 60.2 million in 2006 , the 2010 figure is still remarkable. This statistic forms the basis for transit use cost in the current research.

The average fare for Kelana Jaya Line is RMI.6, which is ealeulated based on the minimum RM0.7 per station and the maximum RM2.5 for full length of trip in 2010 (RapidKL, 2011). The breakdown of total transportation cost in each neighbourhood is indicated in Table 6. 
Table 6: Breakdown of Total Transportation Cost in Each Neighbourhood

\begin{tabular}{|l|c|c|c|}
\hline & Taman Melati & $\begin{array}{c}\text { Taman } \\
\text { Setiawangsa }\end{array}$ & $\begin{array}{c}\text { Taman Teratai } \\
\text { Mewah }\end{array}$ \\
\hline $\begin{array}{l}\text { Auto ownership } \\
\text { cost (RM) }\end{array}$ & 12,979 & 14,061 & 17,306 \\
\hline Auto use cost (RM) & 445 & 570 & 579 \\
\hline Transit cost (RM) & 2,203 & 1,421 & 469 \\
\hline $\begin{array}{l}\text { Transportation } \\
\text { cost (RM) }\end{array}$ & 13,424 & 16,051 & 18,353 \\
\hline
\end{tabular}

It can be seen that in Taman Melati, which has relatively efficient transport coverage, the transportation costs are far less than the other two neighbourhoods. This implies that the lack of public transport in Taman Teratai Mewah does contribute to higher transportation cost. Basically, auto ownership contributes to the higher transportation cost. The study shows that if the total transportation cost as a percentage of household income is deducted from household expenditure, the affordability index is different.

The results of combined housing and transportation costs, as shown by Table 7, indicate that Taman Setiawangsa offers more affordable opportunity than the other two neighbouthoods. Taman Melati is the second affordable area for low- and medium-income residents. Ultimately, Taman Teratai Mewah is not affordable, with risk of spending up to $90 \%$ of household income on housing and transportation.

Table 7: Housing and Transportation Costs in the Thrte Neighbourhoods

\begin{tabular}{|l|c|c|c|}
\hline & Taman Melati & $\begin{array}{c}\text { Taman } \\
\text { Setiawangsa }\end{array}$ & $\begin{array}{c}\text { Taman Teratai } \\
\text { Mewah }\end{array}$ \\
\hline Median income (RM) & 33,000 & 45,500 & 28,500 \\
\hline $\begin{array}{l}\text { Annual transportation costs } \\
\text { (RM) }\end{array}$ & 13,424 & 16,051 & 18,353 \\
\hline $\begin{array}{l}\text { Transportation costs as } \\
\text { percentage of income }\end{array}$ & $40 \%$ & $35 \%$ & $64 \%$ \\
\hline $\begin{array}{l}\text { Average housing cost as } \\
\text { percentage of income }\end{array}$ & $21.2 \%$ & $22 \%$ & $22.4 \%$ \\
\hline $\begin{array}{l}\text { Housing and transportation } \\
\text { cost for owners }\end{array}$ & $66 \%$ & $56 \%$ & $91 \%$ \\
\hline $\begin{array}{l}\text { Housing and transportation } \\
\text { cost for renters }\end{array}$ & $61 \%$ & $54 \%$ & $85 \%$ \\
\hline
\end{tabular}

It was expected that Taman Melati is more affordable than Taman Setiawangsa, however, since the median annual income in this neighbourhood is lower than the other two, affordability index is lower as well. Despite lower 
median houschold income in Taman Teratai Mewah, the affordability is low due to poor pablic transport coverage. The results of this study show that housing provisions without considering the transportation costs is not representing true affordability of a neighbourhood.

\section{DISCUSSION AND POLICY IMPLICATION}

The purpose of this study is to provide guiding prineiples for development of affordable housing with respect to TOD and affordability concepts. The conceptual framework, considers the socio-economic, population density, accessibility, neighbourhood physical characteristics, and auto-use criteria in order to examine the housing and transportation costs. Overall, our findings are consistent with previous research in showing that considering transportation costs incurred by the location and characteristics of neighbourhood is necessary in measuring affordability of a neighbourhood (Holtzelaw et al. 2002; Hess and Almeida 2007; Haas et al, 2008). In addition, unlike the previous studies on measuring the affordability and satisfaction of housing in Malaysian context (Salfarina et al. 2011; Salleh 2008; Mohit et al. 2010), we examined the association of neighbourhood's physical characteristics (e.g Average block size, walkability, etc.) with housing and transportation costs that indicates the extent in which a neighbourhood satisfies the requirements of all income-groups.

Specifically, two dependent variables of auto ownership and auto use were significant predictors of transportation costs, whereby+ access to jobs and public facilities as independent variables contributed more than the others. Consistent with the research on "location effictent neighbourhood" (Holtzclaw et al. 2002) and sustainable housing affordability (Mulliner et al. 2012), our findings suggest that when neighbourhoods are located close to job centres and other urban facilities, residents are most likely to use public transport. This is more apparent when there is a high or medium level of interconnection between residential blocks and transit stations. However, no relation was found in walkability and public transport usage. A possible explanation is that the neighbourhood with high value of walkability has a low interconnectivity index. In contrast, neighbourhoods with low value of walkability have high and medium interconnectivity index. Since walkability is measured by the average block size, smaller block sizes are an indication of greater streets network, where housing and other amenities are within walking distance. However, a high value of walkability cannot indicate better public transport usage if there is a poor interconnection of residential blocks and transit stations. 
The evidence from this study suggests that despite the existence of medium- and high-medium cost housing types, neighbourhoods with good public transportation services have higher affordability index. The other major finding was that combining different modes of transport, motorised and nonmotorised (i.e. walking, bus, train) contribute to higher affordability of the neighbourhood. One explanation for this is that neighbourhoods with high accessibility to different modes of transport incur considerably lower transportation costs than the others. It is interesting to note that the average household's expenditure on transport at the three neighbourhoods ( $40 \%$ at Melati, $35 \%$ at Setiawangsa, and $64 \%$ at Teratai Mewah) in this study is significantly higher than the $2009 / 2010$ national average which is $14.9 \%$ (Department of Statistics Malaysia 2011). This can be explained by the higher auto ownership and use in Kuala Lumpur than the other parts of the country. Alternatively, in this study more factors are considered in calculating the transportation costs (i.e. finance charges, insurance per mile, registration, licenses, and tax per miles) that may not be tised in the government's figure, This is a good reason for providing more varied modes of transport in order to reduce the household's transportation costs.

Our findings suggest that a modified affordability index is an appropriate tool for measuring affordability of a neighbourhood. For this tool the gravity model is replaced by spatial interaction model in measuring job accessibility. In this study, two concepts are added to the $\mathrm{H}+\mathrm{T}$ affordability index. These are the stochastic behaviour of houscholds in selecting the job centre, and the interaction of attractiveness and accessibility in job selection by households. This model has also considered more variables in determining the affordability of a neighbourhood. There are other variables, however, that may be important in decision making such as the number and age of children, multiple occupied homes, especially in studentified areas (Sabri et al. 2010). The spatial factors can also be considered in this model, such as safety and security, weather condition, pedestrian envirenment, and quality of services (Haas et al. 2008).

Such tool can be used to develop a development framework which can accommodate a rapidly urbanising city into a more sustainable urban growth. Central to an entire discipline of TOD is the concept of housing and land use governance. In a federated system of government, the land use governance can be simply conducted by all levels of government (Knaap and Hacco 2007). However, the dominant role in land use govemance is played by local governments (Hawkins 2011). Kuala Lumpur, envisaged to be a world class city is expected to offer a world class living environment having among other things adequate housing and efficient transportation (Kuala Lumpur City Hall 2008 ). 
Although the Kuala Lumpur Master Plan promised to implement Travel Demand Management measures, particularly in increasing public transport usage, a more holistic manner of city design in accordance with TOD principles should be considered to allow affordable housing environment.

\section{CONCLUSION}

The present research adds to the growing literature on combining transport and housing costs to measare affordability. It concludes that improved affordability index, which combines housing and transportation indicators is an appropriate tool for examining affordability of Malaysian neighbourhoods. Based on the implementation of the affordable index in three neighbourhoods of Kuala Lumpur, our findings confirmed the need to address affordability by both the housing and transportation costs.

Despite the deficiencies, this study is able to highlight the impact of spatial characteristics on neighbourhood's affordability. The interactions of transportation, housing market, and socio-economic characteristics are illustrated in constructing the morphology of neighbourhood and the level of satisfactory in living area. More research should be conducted to explain other possible factors based on various neighbourhoods.

\section{ACKNOWLEDGMENT}

The authors would like to express their appreciation to the Universiti Teknologi Malaysia, Johor, Malaysia for sponsoring this research through Fundamental Research Grant Scheme (FRGS) from 2009 - 2011, vote number 78438. Thanks are due to Mr. lsmail Mohd Yusof Deputy Director of Urban Planning Department, City Hall Kuala Lumpur for his generous assistance in providing valuable information for the study. 


\section{REFERENCES}

Aurand, A. (2010). Density, Housing Types and Mixed Land Use; Smart Tools for Affordable Housing? Urban Studies, 47, 1015-1036.

Bank Negara, M. (2010). Bank Negara Malaysia Annual Report 2010. Technical Report Bank Negara Malaysia Kuala Lumpur.

Belzer, D., Hickey, R., \& Lawson, W. (2007). The Case for Mixed-Income Transit-Oriented Development in the Denver Region. Technical Report. Birkin, M., Clarke, G., Clarke, M., \& Witson, A. (1996). Intelligent GIS: Location Decisions and Strategic Planning. Cambridge Science Park, Cambridge, UK: Geoinformation International.

Bogdon, A. S., \& Can, A. (1997). Indicators of Local Housing Affordability: Comparative and Spatial Approaches. Real Estate Economics, 25, 4380.

Calthorpe, P. (1993). The Next American Metropolis: Ecology, Community, and the American Dream. New York: Princeton Architectural Press.

Cervero, R. (2007). Transit-orinted development in the us: Contemporary practices, impacts and policy directions. In Incentives, Regulations and Plans The Rolw of States and Nation-states in Smart Growth Planning (pp, 149-167). Comwall, UK: Edward Elgar Publishing.

Cervero, R., \& Duncan, M. (2001). Rail Transit's Value-Added: Effects of

Proximity to Light and Commuter Rail Transit on Commercial Land Values in Santa Clara County, California, Technical Report National Association of Realtors, Urban Land Institute.

Cervero, R. \& Duncan, M. (2002a). Land Value Impacts of Rail Transit Services in Los Angeles County. Technical Report National Association of Realtors, Urban Land Institute.

Cervero, R., \& Duncan, M. (2002b), Land Value Impacts of Rail Transit Services in San Diego County. Technical Report National Association of Realtors, Urban Land Institute.

Chakraborty, A., \& Mishra, S. (2013). Land use and transit ridership connections: Implications for state-level planning agencies. Land Use Policy, 30, 458-469.

Cheung, R., lhlanfeldt, K., \& Mayock, T. (2009). The Incidence of the Land Use Regulatory Tax. Real Estate Economics, 37, 675-704.

Debrezion, G., Pels, E., \& Rietveld, P. (2007). The Impact of Railway Stations on Residential and Commercial Property Value: A Meta-analysis. The Journal of Real Estate Finance and Economics, 35, 161-180.

Department Of Statistics Malaysia, M. (2011). Household Expenditure Trend 1993/94-2009/10.

Dissanayake, D., Kurauchi, S., Morikawa, T., \& Ohashi, S. (2012). Interregional and Inter-temporal Analysis of Travel Behaviour for Asian 
Metropolitan cities: Case studies of Bangkok, Kuala Lumpur, Manila, and Nagoya, Transport Policy, 19, 36-46.

Duncan, M. (2011). The Impact of Transit-ariented Development on Housing Prices in San Diego, CA. Urban Studies, 48, 101-127.

Glaeser, E. L., \& Gyourko, I, (2001). The Impact of Building Restrictions on Housing Affordability. Federal Reserve Bank of New York Economic Policy Review, 9, 21-39,

Haas, P., Makarewicz, C, Benedict, A., \& Bernstein, S. (2008), Estimating Transportation Costs by Characteristics of Neighborhood and Household. Transportation Research Record: Journal of the Transportation Research Board, 2077, 62-70.

Hawkins, C. V. (2011). Smart Growth Policy Choice: A Resouree Dependency and Local Governance Explanation. Policy Studies Joumal, 39, 679. 707.

Hess, D. B., \& Almeida, T. M. (2007), Impact of Proximity to Light Rail Rapid Transit on Station-area Property Values in Buffalo, New York, Urban Studies, 44, 1041-1068.

Holtzclaw, J., Clear, R., Dittmar, H., Goldstein, D., \& Hias, P. (2002). Location Efficiency: Neighborhood and Socio-Economic Characteristics Determine Auto Ownership and Use - Studies in Chicago, Los Angeles and San Francisco. Transportation Planning and Technology, 25, 1-27.

Hulchanski, J. D. (1995). The Concept of Housing Affordability: Six Contemporary Uses of the Housing Expenditure to Income Ratio. Housing Studies, 10,471-491.

Jacobson, J, \& Forsyth, A. (2008). Seven American TODs: Good Practices for Urban Design in Transit-Oriented Development Projects. Journal of Transport and Land Use, 51-88.

Kahn, M. E. (2007). Gentrification Trends in New Transit-Oriented Communities: Evidenee from 14 Cities That Expanded and Built Rail Transit Systems, Real Estate Economics, 35, 155-182.

Kim, S., Ulfarsson, G., \& Toddhennessy, J. (2007). Analysis of Light Rail Rider Travel Behavior: Impacts of Individual, Built Environment, and Crime Characteristics on Transit Access. Transportation Research Part A: Policy and Practice, 41, 511-522.

Knaap, G.-J., \& Haccou, H. A. (2007). Introduction: Why explone smart growth from a trans-atlantic perspective? In Incentives, Regulations and Plans The Rolw of States and Nation-states in Smart Growth Planning (pp. 116). Cornwall, UK: Edward Elgar Publishing.

Kuala Lumpur City Hall (2008). Druft Kuala Lumpur 2020 City Plan. Kuala Lumpur. 1 . 
Kutty, N. K. (2005). A New Measure of Housing Affordability: Estimates and Analytical Results. Housing Policy Debate, 16, 113-142.

Cho-yam Lau, 1. (2011). Spatial Mismatch and the Aftordability of Public Transport for the Poor in Singapore's New Towns. Cities, 28, 230-237.

Levine, J., Inam, A., \& Torng, G.-W. (2005). A Choice-Based Rationale for Land Use and Transportation Alternatives, Journal of Planning Education and Research, 24, 317-330.

Litman, T. (2007). Evaluating rail transit benefirs: A comment. Transport Policy, 14, 94-97.

Litman, T. (2012). Smart Congestion Relief Comprehensive Analysis Of Traffic Congestion Costs and Congestion Reduction Benefits. Technical Report Victoria Transport Policy Institute.

Govemment of Malaysia, E. M. P. (2001). Eighth Malaysia Plan 2001-2005.

Technical Report.

Govemment of Malaysia, N. M. P. (2006). Ninth Malaysia Plan 2006-2010.

Technical Report.

Govemment of Malaysia, S. M. P. (1996). Seventh Malaysia Plan 1996-2000.

Technical Report.

Govemment of Malaysia, T, M. P. (2010), Tenth Malaysia Plan 2011-2015.

Technical Report.

Molit, M. A., Ibrahim, M., \& Rashid, Y. R. (2010). Assessment of Residential Satisfaction in Newly Designed Public Low-cost Housing in Kuala Lumpur, Malaysia. Habitat International, 34, 18-27.

Mu, R., \& Jong, M. (2012). Establishing the Conditions for Effective Transitoriented Development in China: the Case of Dalian. Jourmal of Transport Geography, 24, 234-249

Mulliner, E., Smallbone, K., \& Maliene, V. (2012). An Assessment of Sustainable Housing Affordability Using a Multiple Criteria Decision Making Method. Omega, 41, 270-279

Nelson, A. C., Pendall, R., Dawkins, C, J. \& Knaap, G. J. (2002). The Link Between Growth Management and Housing Affordability: The Academic Evidence. Technical Report The Brookings Institution.

PolicyLink (2008). Equitable Development Toolkit Building Regional Equity Transit Oriented Development. Technical Report PolicyLink 1438 Webster Street Suite 303 Oakland, CA.

Quigley, J. M., Raphael, S., \& Rosenthal, L. A. (2004), Local Land-use Controls and Demographic Outcomes in a Booming Economy. Urban Studies, 41, $389-421$.

RapidKL, I, P. M. T. D. (2011). Technical Visit to Rapid KL Depot, Subang (I6 June 2010). Web Site.

Rimmer, P. J., \& Dick, H. (2009). The City in Southeast Asia: Patterns, Processes and Policy. NUS PRESS SINGAPORE. 
Sabri, S., M Ludin, A. N., \& Jaffar, A. R. (2010). Geostatistical analysis of studentification: A connection between decision makers and new urban phenomena. In Map Asia 2010 \& ISG 2010.

Salfarina, A. G., Nor Malina, M., \& Azrina, H. (2011). Trends, Problems and Needs of Urban Housing in Malaysia, International Journal of Human and Social Sciences, 5, 1103-1107.

Salleh, A. G. (2008). Neighbourhood Factors in Private Low-cost Housing in Malaysia. Habitat International, 32, 485-493.

Seelig. T., \& Phibbs, P. (2006). Beyond the Normative: Low Income Private Renters' Perspectives of Housing Affordability and Need for Housing Assistance. Urban Policy and Research, 24, 53-66.

Soo, J., Ettema, D., \& Ottens, H. (2008). Analysis of Travel Time in MultiplePurpose Trips. Transportation Research Record: Journal of the Transportation Research Board, 2082, 56-62.

Stone, M. E. (2006). What is housing affordability? The Case for the Residual Income Approach. Housing Policy Debate, 17, 151-184.

Tan, T. H. (2012). Housing Satisfaction in Medium- and High-cost Housing: The Case of Greater Kuala Lumpur, Malaysia, Habitat International, $36,108-116$.

Centre for Transit Oriented Development, C. \& Centre for Neighbourhood, C. T. (2006). The Affordability Index: A New Tool for Measuring the True Affordability of a Housing Choice. Technical Report, The Brookings Institution.

Ministry of Transportation, M. (2010). Transport Statistics.

Weitz, J., \& Waldner, L. S. (2002). Smart Growth Audits. Technical Report American Planning Association.

Winston, C., \& Maheshri, V. (2007). On the Social Desirability of Urban Rail Transit Systems. Journal of Urban Economics, 62, 362-382. 